\title{
THE GOOD, THE BAD, AND THE UGLY: MORAL AGENCY AND THE ROLE OF VICTIMS IN REPARATIONS PROGRAMS
}

\author{
CARLTON WATERHOUSE*
}

\begin{abstract}
In the ongoing debate over reparations for slavery and its legacy in the United States, much of the reparations scholarship pays little attention to the quality of past reparations programs implemented domestically or abroad. ${ }^{1}$ Most commentators emphasize the need for former wrongdoers to make apology, recompense, or restitution rather than looking at results - namely the restoration and recovery of victims. ${ }^{2}$ The problem is not limited to theorists and scholars. Repeatedly, the political contests over guilt and innocence that precede the development of reparations programs obscure consideration of the critical role that
\end{abstract}

* Carlton Waterhouse, Associate Professor of Law, Florida International University, College of Law; B.A. Penn State University; J.D. Howard University; M.T.S. Emory University; Ph.D. Emory University. I would like to thank all the participants who provided valuable feedback during the presentation of this Article at the Comparative Constitutionalism and Rights: Global Perspectives Conference, held in Durban, South Africa. I would also like to thank the Southeastern Association of Law Schools, West Palm Beach, Florida. I would especially like to thank Adjoa Aiyetoro, Bernadette Atuahene, Emma Coleman Jordan, and Michele Anglade for their valuable input and insights. My thanks also extend to Valquisha Morris and Shannon O'Shea for the critical research assistance they provided.

1 See generally WHEN SORRY ISN'T ENOUGH: THE CONTROVERSY OVER APOLOGIES AND REPARATIONS FOR HUMAN INJUSTICE (Roy L. Brooks ed., 1999) [hereinafter WHEN SORRY ISN'T ENOUGH] (offering a comprehensive examination of domestic and international reparations programs).

2 The rejection of reparations as a viable response to past injustice by some commentators coupled with the popular disapproval of reparations for slavery in the United States has led to a narrow emphasis in literature on the legal and moral warrants for reparations. See generally Eric A. Posner \& Adrian Vermeule, Reparations for Slavery and Other Historical Injustices, 103 COLUM. L. REV. 689 (2003) (illuminating the ethical, legal, and institutional problems of reparations programs). But see Alfred L. Brophy, Reconsidering Reparations, 81 IND. L.J. 811 (2006) (arguing that the analysis in Posner and Vermeule's article is too narrow and rigid). 
communities and individuals suffering from past abuses should play in establishing those programs in order to reestablish their personal well-being and societal standing. The resulting focus on wrongdoers replicates the former subordination of the victims of past abuses by rendering them the passive recipients of government actions, over which they have little or no control. This Article advances an important but overlooked measure for evaluating reparations programs: the role of victims in the design and implementation process.

The increased use of reparations by governments to redress past injustices and bring closure to the misdeeds of the past, characterized the latter half of the twentieth century. ${ }^{3}$ While this development, and the accompanying focus upon reparations by the human rights community, represent genuine improvements over the historic neglect of those abused by former regimes, few reparations programs have been particularly "good" when viewed from the victims' perspective. ${ }^{4}$ In fact, when evaluated based on their substantive rather than their symbolic restoration of victims and their families, most programs should be classified as either "bad" or "ugly." My basis for this characterization arises from the failure of most programs to afford injured groups and individuals a meaningful role in the design and implementation of reparations programs. As I have written elsewhere, "[e]fforts to redress past harms can actually be counter-productive, cruel, or insulting when they are not accompanied by actions that attend to both the needs and agency of the injured group." 5 When using these criteria, the

3 Posner \& Vermeule, supra note 2, at 694-98 (reviewing the history of reparation schemes throughout history and noting the recent wave of reparations that constitute the present understanding of the term). See generally ELAZAR BARKAN, THE GUILT OF NATIONS: RESTITUTION AND NEGOTIATING HiSTORICAL INJUSTICES (2000) (providing an analysis of restitution efforts across the globe since World War II).

4 For a variety of perspectives on this topic see WHEN SORRY ISN'T ENOUGH, supra note 1 (critiquing several modern attempts at a program of reparations).

5 Carlton Waterhouse, Avoiding Another Step In A Series of Unfortunate Legal Events: A Consideration of Black Life Under American Law from 1619 to 1972 and a Challenge to Prevailing Notions of Legally Based Reparations, 26 B.C. THIRD WORLD L.J. 207, 222 (2006). As used here, "moral agency" refers to the ability to make moral judgments and to act in accordance with those judgments in the world. See generally WOMEN AND MORAL THEORY (Eva Feder Kittay \& Diana T. Meyers eds., 1987) (exploring the relationship between moral agency and oppressive social norms); SUSAN J. HEKMAN, MORAL VOICES, MORAl SElves: CAROL GILliGAN AND FEMINIST MORAL THEORY (1995) (re-acknowledging the need for women to find their own moral voice so as not to be marginalized by a masculine moral theory). 
inadequacy of most reparations schemes becomes apparent, due to their primary focus on the needs and the moral agency of the former violators. This Article engages the discourse on reparations by focusing on the quality of domestic and international reparations programs in light of their routine failure to attend to the moral agency of the victims of past human rights abuses.

Governments guilty of past injustices may express moral agency through formal apologies or even tacit acceptance of responsibility for past human rights abuses. Through their willingness to acknowledge past injustices and the injuries they caused, governments act as moral agents. Their agency is further expressed through financial or other measures directed toward victims. Historically, victims have been denied this same opportunity to develop agency as most reparations programs limit injured groups and individuals to the passive acceptance of government actions. ${ }^{6}$ This Article maintains that injured parties can best express moral agency through their participation in the development and implementation of reparations programs. This approach will allow injured parties to play an important role in the political community through their participation in the active remediation of their injuries.

This Article consists of three Sections. The first Section briefly examines characteristics of the most common reparations approaches: compensation, restitution, and reconciliation. The second Section assesses the quality of four well-known reparations programs based on their attention to the victims' moral agency in the design and implementation process. The final Section considers an institutional-based approach to reparations as an underutilized means of redress that may best facilitate the moral agency of victims.

6 While victims retain the ability to exercise their agency through the outand-out rejection of government efforts, this take it or leave it approach to reparations frustrates both the reconciliation of the political community and the remediation of victims' harms. See generally ROY L. BROOKS, ATONEMENT AND FORGIVENESS: A NEW MODEL FOR BLACK REPARATIONS (2004) (examining atonement and forgiveness as a complimentary set of moral obligations placed on both perpetrators and victims of past injustices within the context of U.S. slavery and segregation). 


\section{COMMON REPARATIONS APPROACHES}

\subsection{Compensation}

The most well-known approach to reparations requires that wrongdoers pay damages to persons harmed by the wrongdoer's past conduct. Popular among lawyers, compensatory reparations authorize the payment of damages for physical, political, psychological, economic, and other harms suffered. ${ }^{7}$ These reparations can issue from the ruling of a court, the enactments of a legislature, or the funds of a commission responsible for administering transitional justice. ${ }^{8}$ Compensatory schemes range from the establishment of victim funds used for education or health care, to individual payments to the families or descendants of deceased victims. ${ }^{9}$ As a method of making reparations, compensation schemes can be beneficial or deleterious, depending on their design. ${ }^{10}$

Through compensation programs, past violators can offer monetary payments in a collective fund or in individual payments. ${ }^{11}$ Accordingly, their role in reparations can be resolved through a lump sum disbursement or one time payout. Under

7 See Roy L. Brooks, Rehabilitative Reparations for the Judicial Process, 58 N.Y.U. ANN. SuRV. AM. L. 475, 475-77 (2003) (distinguishing compensatory reparations from rehabilitative reparations).

8 See generally BROOKS, supra note 6 (noting some of the avenues pursued by the Black redress movement).

9 Posner \& Vermeule, supra note 2, at 694-98.

10 As discussed below, compensation schemes have accompanied the best and the worst reparations programs. See infra Section 2. See also Hurbert Kim, German Reparations: Institutionalized Insufficiency, in WHEN SORRY ISN'T ENOUGH, supra note 1, at 77, 77-80 (pointing out the harmful insufficiencies in the German reparation scheme to compensate victims of Nazi atrocities); Roy L. Brooks, What Form Redress?, in WHEN SORRY ISN'T ENOUGH, supra note 1, at 87, 88-90 (noting many of the pitfalls associated with Japan's response to "comfort women").

11 See Roy L. Brooks, The Age of Apology, in WHEN SORRY ISN'T ENOUGH, supra note 1 , at 3, 8-9 (previewing various compensatory reparation programs with monetary and non-monetary components); see also Japan's Official Response to Reparations, in WHEN SORRY ISN'T ENOUGH, supra note 1, at 126, 126-31 (outlining the Asian Women's Fund created to distribute reparations to Japanese comfort women); see also Foreign Claims Settlement Comm'n, U.S. Dep't of Justice, German Compensation for National Socialist Crimes, in WHEN SORRY ISN'T ENOUGH, supra note 1, at 61, 61-67 (detailing the reparations made by the Germans in response to the Nazi atrocities). 
either approach, past violators fulfill their obligation through a discrete financial transaction that restores their moral standing and brings ready closure to a shameful past. ${ }^{12}$ Unlike models that require the return of land or property, discussed below, monetary compensation offers a relatively efficient way for those making reparations to bring finality to the process. ${ }^{13}$

Individual payment-based compensation mechanisms also carry some advantages for recipients. Due to their individual nature, they allow recipients to use reparations in the way that they feel best addresses the past harms suffered by them or their family. ${ }^{14}$ Cash payments can be used for innumerable goods and services to redress past harms or meet existing needs or desires. In this way, recipients can exercise autonomy in the reparations process in order to remedy the powerlessness and subjugation they may have suffered in the past. ${ }^{15}$ Accordingly, compensation may be used as a valuable part of a reparations scheme that meets the needs of victims and facilitates their involvement in the reparations process. ${ }^{16}$ However, compensation can represent a cheap payoff or blood money when it fails to reflect the needs or wishes of victims. ${ }^{17}$

\subsection{Restitution}

Restitution represents one of the most wide-ranging reparations options. ${ }^{18}$ Amenable to diverse applications, it can serve to facilitate the return of real and personal property to

12 See infra Section 2.1. (providing four examples of compensatory reparations programs, Germany's response to the Holocaust, Japan's response to the Korean comfort women, America's experience with the Indian Claims Commission, and Argentina's response to the victims of political violence).

13 Id.

14 Id.

15 Id.

16 Id.

17 See infra notes 119-31 (describing the mindset of a subsection of the Mothers of Plaza de Mayo); cf. Mark William Bakker, Comment, Repairing the Breach and Reconciling the Discordant: Mediation in the Criminal Justice System, 72 N.C. L. REV. 1479, 1497-98 (1994) (advocating for a system of restitution instead of incarceration as a way to better serve victims).

18 See, e.g., Elazar Barkan, Restitution and Amending Historical Injustices in International Morality, in POLITICS AND THE PAST: ON REPAIRING HISTORICAL INJUSTICES 91-102 (John Torpey ed., 2003) [hereinafter POLITICS AND THE PAST] (offering multiple examples of nations who have issued restitution and public apologies as a means of acknowledging past wrongs and group suffering). 
previous individual owners, provide stolen wages and lost profits to forced laborers, or repatriate tribes and clans to ancestral lands. ${ }^{19}$ This variety of uses also means that restitution's efficiency, effectiveness, and efficacy varies as well.20 In implementation, restitution can range in procedural and technical complexity, from the intricacies associated with courtroom litigation to the relative simplicity associated with obtaining a driver's license. Schemes can mandate strict burdens of proof requiring documentary ownership rights superior to all others, but may just as readily admit oral histories that establish personal or familial possession during a particular time. ${ }^{21}$ Accordingly, the appeal of restitutionary reparations for past violators as well as victims will vary widely.

Highly technical restitution mechanisms provide past violators with a bureaucratized process that limits the number of recipients through quasi-legal administrative procedures. ${ }^{22}$ Nevertheless, the individualized nature of the claims and the evidentiary burdens result in lengthy claim procedures that may involve repeated court appeals to resolve intractable ownership questions. ${ }^{23}$ As a general matter, these approaches construe reparations narrowly and limit awards to those victims capable of successfully navigating the established procedural hurdles. ${ }^{24}$ Past violators may benefit from these mechanisms by limiting the range of recipients and the scope of restitution in each particular year. ${ }^{25}$ However, the

\footnotetext{
19 Id.

20 Id.

21 Id.

22 Id.
}

23 An alternative approach used by some governments to address land claims provides qualifying claimants with compensation or available land tracts rather than restoration of original lands. Under this policy, governments can avoid the technical and legal challenges associated with resolving competing claims for specific property. Moreover, this methodology offers past violators a more efficient and less costly way to administer restitution programs to a larger number of recipients by decreasing administrative and legal costs. For the claimants, this mechanism offers a less bureaucratic and technical system to recover lost property or its value. In exchange, however, claimants surrender their right to obtain specific property that may have an incommensurable sacramental or sentimental value. Under either approach, Barkan makes clear that restitution awards represent negotiated redress of past injustices that fit into a larger narrative about national identity that reconciles past actions with contemporary notions of justice and desert. BARKAN, supra note 3, at 320-21.

24 Id.

$25 I d$. 
administrative costs and the political exposure associated with slow moving individual based mechanisms can present significant challenges to the long-term viability of these mechanisms. An additional benefit of these means for some past violators will be the ability to construct the future society by determining the beneficiaries of substantial assets reverting to private ownership. ${ }^{26}$ Elazar Barkan makes clear that in Eastern Europe, more often than not, members of the pre-communist middle class typically benefited from restitution schemes. ${ }^{27}$ This results from the temporal nature of restitution and its dependence upon a "rightful ownership" rooted in history. ${ }^{28}$ Rather than restoring property to those with earliest ownership or those "most entitled to it," restitution seeks a particular time that predates a recent injustice to support a claim. ${ }^{29}$ In Eastern Europe, this meant that countries considered restitution claims for property taken under the communist regime, but excluded claims rooted in procommunist property appropriations. ${ }^{30}$ In doing so, governments sought to redress communist injustices but not those of the preceding regimes. ${ }^{31}$ This temporal characteristic creates difficult legal and moral challenges when claimants offer competing prior claims of ownership for restitution. As seen with the history of the United States Indian Claims Commission, discussed below, restitution can be a nightmare for victims. ${ }^{32}$ Although restitution holds the unique potential to return the real and personal property wrongfully taken from victims, the procedures that accompany it can easily deteriorate into a bureaucratic nightmare for victims that can rob the process of its reparative potential. ${ }^{33}$

\subsection{Apology, Atonement, and Reconciliation}

In some cases, reparations take the form of a reconciliation process. These processes consist of apologies and symbolic awards

\footnotetext{
26 Id.

27 Id. at 118-19 (explaining that in Eastern Europe the goal of economic development was often chosen at the expense of a logical, comprehensive and moralistic restitution scheme).

28 See Id. at 118-19.

29 Id.

30 Id. at 120

31 Id.

32 See infra notes 79-87.

33 BARKAN, supra note 3, at 120-21.
} 
or projects as part of a broader process of reconciling victims and those responsible for harming them. ${ }^{34}$ Roy Brooks argues that awards offered in conjunction with an apology constitute atonement by past violators that warrant forgiveness by victims. 35 Under this theory, the reconciliation of the parties represents the primary component of reparations. ${ }^{36}$ The primary goal of these approaches flows from a drive to repair broken relationships caused by past injustices. ${ }^{37}$ Atonement awards represent a symbolic gesture by past violators of the good faith of their apology. ${ }^{38}$ When past injustices resist material redress, symbolic acts provide past violators with an opportunity to show their remorse and commitment not to repeat the unjust behavior. 39 These actions can take a variety of forms including individual compensation awards, community memorial funds, the creation of monuments and museums, the development and support of educational and cultural awareness programs, the establishment of national holidays, and the national commemoration of victims. 40 Most of these activities seek to enshrine the recognition of past injustices in the national memory and to honor the communities or individuals who suffered at the hands of past violators. ${ }^{41}$ In a discussion of the "anatomy of apology" Brooks explains:

34 See Id. at 120. See also Roy L. Brooks, Getting Reparations For Slavery RightA Response To Posner And Vermeule, 80 Notre DAme L. ReV. 251, 274-75 (2004) (explaining that in many cases reconciliation and redress require a degree of remorse that should couple something tangible with the apology in order to be meaningful).

35 BROOKS, supra note 6, at 155-56 (noting the most integral parts of reparations as a reconciliation tool).

36 Id. (discussing an ideal model for reparations to ensure authenticity).

37 Id.

38 Id. See also Roy L. Brooks, Toward A Perpetrator-Focused Model of Slave Redress, 6 AFR.-AM. L. \& POL'y REP. 49, 67 (2004) (explaining that perpetrators must acknowledge guilt through a tangible act demonstrating acknowledgement and also ask for forgiveness in order to mend antagonistic feelings between victims, and sometimes their descendants, and perpetrators).

39 BROOKS, supra note 6, at 155-56. See also Mia Swart, Name Changes as Symbolic Reparation After Transition: The Examples of Germany and South Africa, 9 GERMAN L.J. 105, 107-108 (2008) (discussing the changing of names as a restorative measure to aid in the victim rehabilitation process).

40 BROOKS, supra note 6, at 156.

41 Id. See also Swart, supra note 39, at 106 (noting that the changing of a street name can have at least three functions: a vehicle for commemoration, a form of symbolic reparation for human rights abuse, and constructing a politicized version of history). 
A tender of apology is no trivial matter, particularly when made by state officials on behalf of their governments. It is an act fraught with deep meaning and important consequences.

Let us begin with some understanding of what apology is and is not in the context of atonement. Apology, most importantly, is an acknowledgment of guilt rather than a punishment for guilt. When a government perpetrates an atrocity and apologizes for it, it does four things: confesses the deed; admits the deed was an injustice; repents; and asks for forgiveness. ${ }^{42}$

This process and other reconciliation efforts offer victims recognition and standing in the current social order and allows past violators to regain moral standing domestically and internationally. ${ }^{43}$ Although these mechanisms themselves can provide past violators with the smallest financial burden associated with reparations, the strong repudiation of the behavior of past regimes as well as the fear of future civil suits can deter governments from adopting this approach because of its political and/or psychic costs. ${ }^{44}$ In contrast, victims focused on current societal standing, as well as those focused on addressing the emotional cost of a painful history, may gravitate toward reconciliation as a reparations mechanism because of the social and psychic benefits it provides. ${ }^{45}$

42 BROOKS, supra note 6, at 144 (emphasis in original). Brooks goes on to note that government-based apologies play the vital role of clarifying often contentious historical records regarding past injustices. Id. at 148-51. In South Africa, the need to elaborate the record of past injustices led to a grant of amnesty for perpetrators of gross human rights abuses in exchange for open testimony detailing the atrocities inflicted during the previous regime. See generally DESMOND MPILO TUtU, No Future WITHOUT ForgIVENESS (1999) (explaining the South African reconciliation process and the subordination of retributive justice in order to discover the truth about the past).

43 BROOKS, supra note 6, at 144-48. Additionally, Elazar Barkan argues that at the very minimum these apologies lead to a reformulated historical understanding that is itself a form of restitution and becomes a factor in contemporary politics and humanitarian actions. BARKAN, supra note 3, at 98-99.

44 In 1996, Australia elected a more conservative government that deemphasized and de-funded the reconciliation efforts of the previous administration. This exemplifies how a government might reject reconciliation in order to preserve dominant political ideologies the roots of which can be found in historic notions of national identity. See BROOKS, supra note 6, at 153.

45 See id. at $143,170$. 
The contemporary focus on truth commissions works within the reconciliation model because of its ability to promote healing between victims and violators in the wake of gross human rights abuses. 46 These commissions take diverse approaches, but regularly focus on unveiling the mystery surrounding the fate of disappeared and murdered community members. To facilitate this, governments may offer amnesty to perpetrators of human rights abuses in exchange for their testimony. ${ }^{47}$ This mechanism allows societies to promote healing between perpetrators and victims using amnesty and confessions rather than tribunals and retribution. 48 The clandestine nature of many abuses in such countries as South Africa and Chile has created considerable angst about the death and disappearance of countless loved ones. ${ }^{49}$ The truth and reconciliation commissions in these and other countries facilitate a very public process of confession, in order to allow perpetrators and victims to reconcile and shape a new future for their society. ${ }^{50}$ Unfortunately, in both South Africa and Chile, officials and other known perpetrators refuse to participate in criminal prosecution and confession. Their lack of participation raises questions about the effectiveness of the reconciliation process.

46 Id. at 147-148.

47 Id.

48 Truth commissions offer possibilities for moving beyond political violence at a collective level. This is partly a consequence of their public recognition of suffering and collaborative efforts to understand the complete story of the past. See MARTHA MinOW, BETWEEN VENGEANCE AND FORGIVENESS 79 (1998); see generally Roslyn Myers, Truth and Reconciliation Commissions 101: What TRCs Can Teach the United States Justice System About Justice, 78 U.P.R. JUR. REV. 95 (2009) (recounting the purpose and the effectiveness of truth and reconciliation commissions).

49 See MinOw, supra note 48, at 66-70 (describing the emotional consequences and the restorative power of truth commissions in South Africa and Chile).

50 Id.; see also Myers, supra note 48, at 115-16 ("In the South African TRC, the needs of the victims drove the proceedings: the victims' pursuit of information about what happened to loved ones who disappeared; their need to have their suffering acknowledged by the wider community; their desire to hear perpetrators admit to their abuses; and their hope to have the local and international community react with indignation and empathy."); see generally Naomi Cahn, Beyond Retribution and Impunity: Responding To War Crimes of Sexual Violence, 1 STAN. J. CIV. RTS. \& CIV. LIBERTIES 217, 219 (2005) (exploring possible responses to "crimes of sexual violence in the context of post-conflict justice"). 


\section{REPARATIONS RECONSIDERED}

The historic implementation of reparations schemes across the globe often consists of a mixture of the above approaches. In some cases, governments limit reparations exclusively to one of the above mechanisms, while in exceptional cases governments implement a comprehensive scheme using a configuration of all the above mechanisms. ${ }^{51}$ The Federal Republic of Germany ("FRG") provides the seminal case of comprehensive reparations. In that instance, the FRG used compensation, restitution, and reconciliation in providing redress for the victims of the Holocaust. ${ }^{2}$ The program used by Germany included compensation to individual victims and the state of Israel, restitution for stolen property and forced labor, apology, and a variety of domestic reconciliation projects. ${ }^{53}$

Unlike reparations undertaken by the FRG, most reparations schemes routinely emphasize the actions of past violators to define and evaluate reparations, thereby maintaining the continued subordination of victims and the primary importance of violators. ${ }^{54}$ This approach can provide past violators with an almost unilateral ability to decide, if, when, and how to make reparations, with little regard to the victims' views or role in the design and implementation of reparations programs. 55 The actions of victims under this model are a secondary consideration relative to the chief

51 Roy L. Brooks, Reflections on Reparations, in POLITICS AND THE PAST, supra note 18, at 106-07; see also Note, Bridging the Color Line: The Power of AfricanAmerican Reparations To Redirect America's Future, 115 HARV. L. REV. 1689 (2002) (arguing the need for reparations in order to heal the racial divide in the United States).

52 Brooks, supra note 51, at 108, 112.

53 See United States Dep't of Justice, Foreign Claims Settlement Commission, German Compensation for National Socialist Crimes, in WHEN SORRY ISN'T ENOUGH, supra note 1, at 61-65 (describing Germany's reparations to victims of the Holocaust).

54 Theo Van Boven, Victims' Rights to a Remedy and Reparation: The New United Nations Principles and Guidelines, in REPARATIONS FOR VICTIMS OF GENOCIDE, WAR CRIMES AND CRIMES AGAINST HUMANITY 19-21 (Carla Ferstman, Mariana Goetz, \& Alan Stephens eds., 2009) (highlighting the growing recognition of reparations in human rights discourse responds to this phenomenon by elevating the significance of victims rights in reparations programs).

55 Id; see also Naomi Roht-Arriaza, Reparations Decisions and Dilemmas, 27 HASTINGS INT'L \& COMP. L. REV. 157, 170-72 (2004) (describing the reparation methods employed by various South American countries in the wake of the military dictatorships occurring from 1970-1990). 
concern over what actions past violators take.56 The typical reparations scheme also provides inadequate attention to the material needs of victims. ${ }^{57}$ Instead, these approaches emphasize the restoration of the moral standing of past violators in the political community. This routinely manifests in reconciliation efforts intended to symbolize the restoration of social harmony within the political community. ${ }^{58}$ These efforts regularly sacrifice attention to the material needs and losses of past victims in favor of restoring social accord among community members. Instead of a careful assessment of the steps required to enable victims to overcome the deficits of past injustices, reparations typically emphasize the remorse and regret of violators over the needs of victims. ${ }^{59}$ While all of the above efforts can represent important aspects of good reparations programs, they hinder effective reparations when they are out of balance with the proper attention to the wellbeing and engagement of past victims. ${ }^{60}$

The result of the imbalance manifests in negative and harmful consequences that undermine the ultimate efficacy of reparations programs. The first of these is the continued subordination of victims relative to governmental actors. Most reparations programs reflect government efforts to redress past governmental harms perpetrated against citizens or other residents of a country. ${ }^{61}$ Because the original wrongs redressed by reparations flowed from the misuse or abuse of government power relative to persons or

56 See generally WHEN SORRY ISN'T ENOUGH, supra note 1 (collecting various authors' accounts of the multitude of reparations regimes in the latter half of the twentieth century).

57 See Pablo de Greiff, Justice and Reparations, in THE HANDBOOK OF REPARATIONS 451, 457-58 (Pablo de Greiff ed., 2006) (discussing the similar shortcomings between the reparations schemes from South Africa, Peru, and the victims of September 11); see also Cecily Rose, Looking Beyond Amnesty and Traditional Justice and Reconciliation Mechanisms in Northern Uganda: A Proposal for Truth-Telling and Reparations, 28 B.C. THIRD WORLD L.J. 345, 385-86 (2008) (discussing the Ugandan government's failure to respond to the victims' need for reparations while granting amnesty and resettlement packages to the perpetrators).

58 See Van Boven, supra note 54, at 2 (arguing that one purpose of the commission is to correct social history).

59 For an examination of the role of regret in reparations policy see Jeffrey $\mathrm{K}$. Olick \& Brenda Coughlin, The Politics of Regret: Analytical Frames, in Politics in the Past 37 (John Torpey ed., 2003).

60 See Van Boven, supra note 54, at 19 (stating that remorse plays a key role when styling systems of reparations).

61 See generally WHEN SORRY ISN'T ENOUGH, supra note 1. 
groups within a society, the creation of reparations based primarily on government concessions or symbolic gestures to past victims can continue the neglect of those harmed. ${ }^{62}$ Consequently, government violators may avoid responsibility for the deterioration of victims' socio-economic conditions following reparations or reconciliation efforts by noting that, in light of their attempted corrections, any failure by victims to succeed is unrelated to past injustices. ${ }^{63}$ This rationale can easily become the dominant discourse in societies where victims belong to minority groups that suffered historic mistreatment. ${ }^{64}$ In these cases, officials and other segments of society expect victimized persons and communities to compete equally, despite the failure of reparations schemes to adequately redress the harms caused by past injustices. ${ }^{65}$

An equally significant shortcoming in many reparations schemes takes place in the design process. When countries contemplate ways to overcome the misdeeds of the past, they may see victims as passive agents who receive compensation or accept symbolic gestures as recognition of their mistreatment. ${ }^{66}$ This view of victims fails to recognize the importance of victims' active engagement in the reparations process, from its design and implementation, to its conclusion and evaluation. ${ }^{67}$ Victims'

62 For consideration of the overwhelming rejection of the Asian Woman's fund by the surviving Korean Comfort Women and other groups see infra notes 100-110 and accompanying text.

63 See Bernadette Atuahene, From Reparations to Restoration: Moving Beyond Restoring Property Rights to Restoring Political and Economic Visibility, 60 SMU L. REV. 1419, 1444-445 (2007) (maintaining that a society dedicated to moral restoration must find a way to integrate victims of atrocities into the social fabric to affirm their humanity).

64 Many contemporary views in American society regarding African Americans reflect this phenomenon. See JOE FEAGIN, RACIST AMERICA: ROOTS, CURRENT REALITIES AND FUTURE REPARATIONS 105-36 (Routledge 2001).

65 Id. at $127-128$.

66 The official Japanese response to the harms done to Korean comfort women serves as one example. Japan's Official Responses to Reparations, supra note 11 , at $126-31$.

67 The International Criminal Court awards victims the right to participate other than as witnesses in the court proceedings providing their participation does not infringe upon the rights of the accused. Under this new framework, victims have the right to counsel, and at present, victims' participation extends to issues over reparation claims, jurisdiction, investigations, indictments, amendments, interim release, and disclosure, question of witnesses, admissibility and relevancy of evidence, sentencing and other decisions of the court. Brianne N. McGonigle, Bridging the Divides in International Criminal Proceedings: An 
participation in the design of reparations enables them to see themselves healing and to articulate the steps needed to see that healing accomplished. Moreover, victims' involvement in the design process enables them to make sacrifices as well as demands, in order to promote the good of the larger community in addition to their own. ${ }^{68}$ Further, victims' involvement in designing reparations also helps elevate their status in the reparations process in its initial stages, increasing the likelihood that they will be included as equal parties throughout. ${ }^{69}$

In the implementation stages, victims' ability to participate actively in a reparative process bolsters their healing, as well as the society's advancement. Through active participation and engagement, victims become vested participants in a reformed or changed society, transcending their former identity as those aggrieved by a former regime. ${ }^{70}$ This visible engagement, accompanied with the support needed to overcome past mistreatment, not only provides superior short-term benefits for victims, but also improves the long-term prospects for healing societal wounds by increasing victims' ability to overcome the harms of the past and to take part in society. ${ }^{71}$ This approach can decrease the likelihood that bitterness and anger will pass down through generations to destabilize countries long after original transgressions. Although the shape of reparations programs should always reflect the context of the situation and the country in which they take place, below the Article elaborates on how institutional development represents one way that victims of reparations can actively engage in the reparative process and meaningfully exercise their moral agency.

Examination into the Victim Participation Endeavor of the International Criminal Court, 21 FLA. J. INT'L L. 93, 110-111 (2009) (discussing victims' participatory role in international criminal proceedings when dealing with issues such as reparations).

68 Barkan, supra note 18 , at 93.

69 Id. (describing the successes of the Roma people due to the increased attention given by the European Union)

70 Id.

71 At a minimum, healing denotes re-establishing a connection to the meaning in life, in such a way that victims contemplate a future for themselves. See Myers, supra note 48, at 90 (emphasizing the need for victims to be the focal point in the healing process). 


\subsection{Reparations Cases Reviewed}

Reparations typically flow from efforts to redress historical practices that contemporary moral theory deems anathema. ${ }^{72}$ Current understandings of reparations, as a practice related to individuals or groups rather than entire countries, can be traced back to the Federal Republic of Germany's response to the gross atrocities committed by Nazi Germany. ${ }^{73}$ This resulted in the first provision of reparations to a non-state entity. In the wake of the Holocaust, the Federal Republic of Germany provided a robust reparations scheme. ${ }^{74}$ The program provided for three reparations mechanisms to redress Nazi atrocities: first, supplying the State of Israel with goods and services; second, directly compensating Jews victimized by Nazi's; and third, funding the relief and resettlement of persecuted Jews to Israel. ${ }^{75}$

Another reparations case related to World War II is that of the Korean Comfort Women. This matter originated in the sexual enslavement and forced prostitution of women and girls by the Japanese army from 1931 to $1944 .{ }^{76}$ During this period, Japan used deception and abduction to force some two hundred thousand, mostly Korean, women and girls into prostitution. ${ }^{77}$ In response to international and domestic pressure, Japan established a

72 See Ruti TeITEl, Transitional Justice 119 (2000) (discussing reparations and the conception of justice as contextualized and partial because what is deemed just is contingent and informed by prior injustice); see also Posner \& Vermeule, supra note 2, at 694-95 (illustrating how modern reparations schemes respond to tragedy).

73 United States Dep't of Justice, supra note 53, at 61-67.

74 Id. at 62.

75 Id. See also Posner and Vermeule, supra note 2, at 694 ("[T]he Holocaust case differs from the standard cases of coerced wartime reparations. The Holocaust reparations did not go to the victorious powers, and the program emerged more or less autonomously from the German political system ...."). See generally Kurt Schwerin, German Compensation for Victims of Nazi Persecution, 67 Nw. U. L. REV. 479 (1972) (detailing the process that went into Germany creating laws and establishing proceedings to compensate the victims of Nazi Persecution); Roy L. Brooks, The Slave Redress Cases, 27 N.C. CENT. L.J. 130, 141-42 (2005).

76 BARKAN, supra note 3, at 47. See Brooks, supra note 10, at 88-90 (explaining the use of the Korea's Comfort Women as prostitutes for the Japanese army).

77 United States Dep't of Justice, supra note 53, at 126-31. See also Waterhouse, supra note 5, at 222 ("Japan's handling of reparations for Korean comfort women during War World II . . . provide[s] examples of how government-based reparations programs often frustrate, rather than fulfill, efforts to redress the wounds of past injustice."). 
reparations fund for surviving victims and the Japanese prime minister personally apologized for the atrocities. ${ }^{78}$ In the wake of World War II, the United States began its own reparations process for Native Americans with the establishment if the Indian Claims Commission ("ICC"). Beginning in 1946, the ICC presided over the restitution and reparations of tribal claims against the United States and its citizens for the taking of Indian properties, treaty violations, and other infractions against tribes and their members. ${ }^{79}$

One less well-known but equally interesting reparations case is found in the Argentinean response to the political violence carried out by successive military regimes from 1975 and 1983.80 During the period, known as the "Dirty War," 15,000 to 30,000 civilians were killed. ${ }^{81}$ In addition to the military regimes' detention, torture, and incarceration of those believed to have leftist connections, large numbers of civilians were taken by the military executed and without admission, acknowledgement or the return of their remains. 82 These became known as the "disappeared." 83 To redress these grave human rights abuses, subsequent democratic governments approved a number of compensation and other programs for the broad classes of persons who suffered under the regime. ${ }^{84}$ The initial laws passed reinstated public servants, employees of state controlled companies, teachers, and bank workers dismissed for political reasons. ${ }^{85}$ A second set of laws provided pensions to the spouses and children of the disappeared that included health care and pharmaceutical

78 George Hicks, The Comfort Women Redress Movement, in WHEN SORRY ISN'T ENOUGH, supra note 1, 113, 118.

79 Nell Jessup Newton, Indian Claims for Reparations, Compensation, and Restitution in the United States Legal System, in WHEN SORRY ISN'T ENOUGH, supra note 1, at 261-66. See also Zachary F. Bookman, Note, A Role for Courts in Reparations, 20 NAT'L BLACK L.J. 75, 86-87 (2006) (explaining how the government sanctioned reparations program for Native Americans fail to address the needs of the very people they are trying address).

80 Maria Jose Guembe, Economic Reparations for Grave Human Rights Violations: The Argentinian Experience, in THE HANDBOOK OF REPARATIONS, supra note 57 at 21, 21-22.

81 Christina Marie Wilson, Note, Argentina's Reparation Bonds: An Analysis of Continuing Obligations, 28 FORDHAM INT'L L.J. 786, 794 (2005).

82 Id. at 794-95.

83 Id.

84 Guembe, supra note 80 , at 31-44.

85 Id. at 23-24. 
benefits. 86 Subsequently, numerous laws were passed to provide substantial compensation for detainees, the successors of the assassinated and the disappeared, persons born while their mothers were detained, minors detained or held based on their parents' detention, children sold or wrongfully placed with other families due to their parents' detention or disappearance, and those forced into exile. ${ }^{87}$

Looking at the four reparations programs above, under this analysis, none could be considered good, two could be considered bad, and two could be considered ugly. The FRG program for Jewish victims of the Holocaust represents the most sweeping and extensive reparations program in modern history. .8 Though some consider it a highly successful reparations program, under my analysis, it approximates a good program yet still falls short. ${ }^{9}$ Because the program grew out of negotiations with a wellorganized group representing Holocaust victims, the mechanism reflected a deeper appreciation for victims' wishes and desires than most. ${ }^{90}$ Moreover, the program directed substantial resources that supported institutional development in Israel which would benefit victims over the long term. This aspect was reflected in Germany's provision of goods and services to Israel as well as by the

86 Id. at 26.

87 Id. at 31-44.

88 German Compensation for National Socialist Crimes, in WHEN SORRY ISN'T ENOUGH, supra note 1, at 61-67. See also Kim, supra note 10, at 77-78 ("Unprecedented in its scale, the German plan has been extolled as a model redress scheme, with few doubting Germany's willingness to accept its moral responsibility for the dark chapters of its Nazi past, or its genuine desire to compensate those it victimized.").

89 Roy L. Brooks, A Reparations Success Story, in WHEN SORRY ISN'T ENOUGH, supra note 1, at 17. See generally Menachem Z. Rosensaft \& Joana D. Rosensaft, The Early History of German-Jewish Reparations, 25 FORDHAM INT'L L.J. 1, S-1 (2001) (explaining that although the voluntarily negotiated reparations program had a profound impact on German-Jewish relations, it is unlikely that anyone paid much attention to the relatively insubstantial individual claims of the Holocaust survivors).

90 It bears noting that the quick response following the end of the war effectively increased the overall accomplishments of the program. In most of the other cases considered, the substantial time lag between the harms inflicted upon victims and the decision to provide redress significantly hindered the success of the program. Expeditious attention to the development of reparations programs increases both the quantity and quality of victim participation. Even when enduring hostilities impede expeditious attention to reparations, a government can improve the quality and the effectiveness of reparations programs by engaging a reparations process at the conclusion of hostilities. 
resettlement of persecuted Jews to Israel. ${ }^{91}$ Although this mechanism failed to achieve the goal of reforming institutions within German society that allow the active engagement and participation of victims in the type of reparative process articulated above, it served a similar function by supporting the development of a society focused on and committed to creating and sustaining those institutions. Consequently, Israel's development as a society provided Holocaust victims with both the responsibility and the opportunity to participate in their own repair and restoration. In terms of the victims' moral agency, the FRG program provides significant glimpses of how prioritizing victims' engagement in the design and implementation of reparations can help improve the long-term success of reparations programs by supporting victims' participation in their own repair and restoration.

Unfortunately, the FRG program still suffered from substantial problems that mar its standing as a model for future reparations programs. The limited scope of the program in reaching all the victims of the Nazi regime, particularly Eastern European Jews, Roma, and homosexuals, was one significant flaw. The inadequacy of the assistance provided former victims was another. ${ }^{92}$ These issues keep the FRG settlement from being classified as "good."

The reparations for Korean comfort women and the ICC exemplify bad reparations programs. In both cases, the victims played a minimal role in the program design, development, and implementation. ${ }^{93}$ Instead, Japanese and American bureaucrats respectively created a scheme and then informed the victims of its existence. This top-down approach to reparations increases the likelihood that programs will fail to redress past injustices in a meaningful way.

Through legislation following World War II, the United States established the ICC to settle all Indian claims that arose before 1946. ${ }^{94}$ Although the ICC made some monetary awards, claimants found themselves enmeshed in highly technical adversarial litigation against the Department of Justice that frustrated and

91 Foreign Claims Settlement Comm'n, United States Dept. of Justice, German Compensation for National Socialist Crimes http://www.ushmm.org/assets /frg.htm (last updated March 6, 1996).

92 Kim, supra note 10 , at 77-80.

93 Id.

94 Id. 
impeded their success. ${ }^{95}$ Despite its substantial and unique importance to claimants, the ICC refused to provide the restoration of land rights. ${ }^{96}$ The victims suffered additional adversity in the process through their interaction with private counsel, whose interests often differed from their clients and resulted in the loss of claims. ${ }^{97}$ Although Congress authorized a less formal and more cooperative program through its legislation, allowing the Commission to address moral as well as legal claims, the ICC gave little thought to the effect of the program on victims, and imposed a rigid legal structure that marginalized claimants and their cultural perspective. ${ }^{98}$ Instead, victims had to prove claims and meet substantial procedural barriers to participate in the program. Beyond this, the adversarial nature of the proceedings alienated victims and frustrated attempts to obtain restitution for the gross injustices they suffered. The ICC process not only neglected the moral agency of victims to participate actively in the repair or restoration of their communities and their well-being, but also failed to provide sufficient restitution for many claimants in light of the losses they suffered. ${ }^{99}$

Likewise, the fund set up by the Japanese parliament for the "Korean Comfort Women" suffered from the insufficient participation of victims in its design and intended operation. ${ }^{100}$ Under the program, the Japanese government created the "The Asian Women's Fund" for the benefit of former comfort women.101 The Japanese Parliament only funded administrative operations, however, and left it up to the Japanese people to fund the corpus through their charity. ${ }^{102}$ The fund made amounts available to "support medical and welfare projects" which would "be of

95 Id.

96 Newton, supra note 79, at 263-267.

97 Id. at 264.

$98 \mathrm{Id}$. at 263. See generally GEORGE HiCKS, THE COMFORT WOMEN: JAPAN'S BRUtal Regime of ENFORCEd Prostitution in the SECOND WORLd WAR (1995) (detailing an in-depth examination of the history of the "comfort women" and the events leading up to the development of the fund).

99 Newton, supra note 79, at 263-64.

100 Id. See also Byoungwook Park, Comfort Women During WWII: Are U.S. Courts A Final Resort For Justice?, 17 AM. U. INT'L L. REV. 403 (2002) (explaining how the Comfort Women face an ongoing, difficult task of getting their claims settled).

101 Japan's Official Responses to Reparations, supra note 11, at 129-131.

102 Id. 
service" to the former comfort women and Fund representatives engaged in dialogues with former comfort women regarding projects that the fund might undertake. ${ }^{103}$ Ultimately, the fund provided "atonement money" for each individual consisting of approximately $\$ 17,000$ (U.S.), a letter of apology from both the Prime Minister of Japan and the Fund President, and access to some medical services to less than 20 women in the Republic of Korea. ${ }^{104}$

Rather than meaningfully aiding Korean women, the fund further stigmatized and marginalized past victims who saw it as a provision of charity donated by Japanese citizens, rather than a just compensation scheme as requested by victims and others. 105 The program failed to recognize the cultural context of victims and neglected to address their numerous concerns. ${ }^{106}$ The fund also placed a burden on victims to prove their victimization. ${ }^{107}$ Further, the Japanese government failed to accept responsibility for the deception and force used to abduct and sexually enslave over one hundred thousand Korean women. ${ }^{108}$ Out of protest against the Japanese government, few of the nearly 200 surviving victims participated in the program. To support victims rejecting the Japanese award, the South Korean government provided comparable benefits to Korean victims who refused the Japanese offer. ${ }^{109}$

The reparations program Japan implemented was doomed from the onset due to its failure to take meaningful account of the surviving Korean comfort women's moral agency in the program's initial design and subsequent development.110 Rather than honoring the victims' views and working collaboratively with

103 Id. See also Jon M. Van Dyke, Reconciliation between Korea and Japan, 5 CHINESE J. INT'L L. 215, 234-35 nn.104-109 (2006) (explaining how funds would be distributed amongst the many different Comfort Women victims).

104 The Comfort Women Issue and the Asian Women's Fund, http:/ / www.awf.or.jp/e3/korea.html (last visited Nov. 1, 2009).

105 Hicks, supra note 78, at 113, 124.

106 Id. See generally Mary Margaret Penrose, Impunity-Inertia, Inaction, and Invalidity: A Literature Review, 17 B.U. INT'L L.J. 269, 300-02 (1999) (detailing how the Japanese government disturbingly continues to avoid legal responsibility and liability for its appalling system of Comfort Women).

107 Guembe, supra note 80, at 36-37.

108 Hicks, supra note 78, at 122.

109 The Comfort Women Issue and the Asian Women's Fund, supra note 104.

110 Id. 
them to establish an acceptable program of reparations, the government initially refuted responsibility and only sought "dialogue" with victims as an afterthought. Japan further alienated the Korean victims in two ways.111 By offering meager awards to survivors, the Japanese government conveyed the message that these atrocities were mere inconveniences rather than drastic blows to the mental and physical health of the victims. Japan also alienated victims by refusing their request to identify and publicly acknowledge the responsibility of the perpetrators of the atrocities. ${ }^{112}$

The Argentinean reparations program represents one of the most broad and victim-focused reparations programs to date. The compensation mechanism used in most instances calculated victim remuneration levels based on the compensation and benefits provided to the highest-ranked civil servants. ${ }^{113}$ This formula established a spectrum of financial redress dependent upon the harm suffered.114 The program provided both financial and healthcare benefits to families who had lost the material support of one or more members due to the forced disappearance exacted by the former regimes.115 The substantial depth of the support was complemented by the breadth of the program which extended across the range of the government's victims and even included foreign nationals within Argentina who suffered during the "Dirty War."116

The extension of reparations to the full range of the military regimes' victims was steady but far from immediate-it took the government a little over a decade to pass the most important reparations legislation, some of which extended reparations to additional categories of victims. ${ }^{117}$ Argentinean human rights groups played a significant role in reparations discussions over the two decades. ${ }^{118}$ While the specific details of their involvement

111 Id.

112 Hicks, supra note 78, at 122-23.

113 Guembe, supra note 80, at 30.

114 The program awarded detainees compensation based on the length of detainment with increased amounts for injuries suffered while detained and a maximum increase for those who died during detention. Id. at 32.

$115 I d$. at 26.

116 Id. at 42 .

117 Id. at 27.

118 Guembe, supra note 80, at 22. 
warrant further examination, the influence of victims' groups, including the two organizations making up Mothers of Plaza de Mayo, seem clear.119 Government reparations programs sought and were responsive to the input of victims, their families and the organizations that represented them. ${ }^{120}$ Nonetheless, when examined closely, the case highlights important challenges facing both compensation programs and victim participation in the design of an appropriate reparations program. A substantial disagreement took place within Mothers of Plaza de Mayo regarding reparations for the families of the disappeared. ${ }^{121}$ One group, Mothers of Plaza de Mayo Association, opposed reparations whether economic or simply in the form of an apology from the government. ${ }^{122}$ They maintained that families receiving economic reparations were "prostituting" themselves. ${ }^{123}$ The other group, Mothers of Plaza de Mayo-Founding Group, took a contrary position. ${ }^{124}$ They supported reparations and contended that families should have the choice of claiming reparations or not on behalf of disappeared loved ones. ${ }^{125}$ The government finally adopted this approach-making reparations an optional benefit available to victims' families. ${ }^{126}$ Because the vast majority of victims' families and their advocate groups endorsed this approach, the difference of opinion within the community was readily resolved. Despite the risk of disagreement, however, reparations programs that reflect the views, needs, and desires of victims have greater legitimacy and effectiveness. ${ }^{127}$

Despite the foregoing, Argentina's program falls short of the attributes of a "good" program. Though the harms addressed and the beneficiaries covered were extensive, the program was somewhat marred by the nature of the reparations. The use of

119 Id. at 38-39.

120 Id.

121 Id. at 25.

122 Id.

123 Guembe, supra note 80 , at 38.

124 Id. at 25.

125 Id. at 38.

126 Id.

127 It is true that governments risk being placed between competing views of reparations and potentially losing popular and political support for programs ultimately developed. However, they can obviate that risk through the use of consensus-building mechanisms within organizational structures created to facilitate victim participation in the design of a reparations program. 
public bonds by a poor and weak state did not guarantee reparation awards. Also, the fact that recipients had to wait sixteen years to redeem the bonds, although both capital and interest payments were to be paid in the interim, hampered compensation. ${ }^{128}$ Due to a debt crisis in 2001, Argentina defaulted on its internal and external debt obligations, including reparations bonds. ${ }^{129}$ This resulted in the reduction of the value of some awards by as much as $70 \%$ and the temporary suspension of capital and interest payments to the beneficiaries. ${ }^{130}$ Since 2001, victims holding reparations bonds have lacked certainty regarding the extent of the economic support they can finally expect under the plan. Moreover, by conditioning reparations awards on bond redemption, the government placed beneficiaries at risk of default and within the structure of a highly technical securities mechanism that can be difficult to navigate. ${ }^{131}$ As a result, this program, like the FRG's, falls somewhere between good and ugly.

Consistent with the growing number of reparations and restitution-based actions worldwide, the United Nations formally addressed these issues in the 1990s through the work of the U.N. Sub-Commission on Prevention of Discrimination and Protection of Minorities. ${ }^{132}$ This Sub-Commission's work, formally developed through the efforts of Special Rapporteurs, Theo van Boven and M. Cherif Bassiouni, ultimately resulted in the U.N. General Assembly adopting the Basic Principles and Guidelines on the Right to a Remedy and Reparation for Victims of Gross Violations of International Human Rights Law and Serious Violations of International Humanitarian Law in 2006.133 This Resolution

\footnotetext{
128 Guembe, supra note 80 , at $40-41$.

129 Wilson, supra note 81 , at 788-89.

130 Id. at 789. See also Guembe, supra note 80, at 41 (detailing the suspension of capital and interest payments to beneficiaries).

131 Guembe, supra note 80, at 44.

132 United Nations General Assembly, Draft: Basic Principles and Guidelines on the Right to a Remedy and Reparation for Victims of Gross Violations of International Human Rights Law and Serious Violations of International Humanitarian Law, (2004) available at http://www2.ohchr.org/english/events/meetings/docs/versionrev .doc (Original draft of G.A. Res. 60/147). See generally Zakia Afrin, Foreign Direct Investments and Sustainable Development in the Least-Developed Countries, 10 ANN. SURV. INT'L \& COMP. L. 215, 223-24 (2004) (discussing a United Nations Resolution addressing norms on the responsibilities of transnational corporations and other business enterprises with regard to human rights).

133 Basic Principles and Guidelines on the Right to a Remedy and Reparation for Victims of Gross Violations of International Human Rights Law and Serious
} 
adopted principles that present specific obligations on states guilty of human rights violations. ${ }^{134}$

The principles in the Resolution relating to victims of human rights violations formally acknowledge restitution and compensation as remedial or reparative mechanisms to address past injustices. ${ }^{135}$ The aforementioned reparations cases also envisioned diverse means and mechanisms for addressing historic injustices. Redress, restitution, reconciliation, remediation, rehabilitation, recollection, retribution, compensation, and apology are all terms that have been associated with the issue of reparations.136 The shared characteristic of each of these terms is an intention to correct or otherwise harmonize the past and the present. As a compliment to these mechanisms, this Article proposes an institutional model of reparations that promotes the

Violations of International Humanitarian Law, G.A. Res. 60/147, U.N. Doc. A/RES/60/147 (Mar. 21, 2006) [hereinafter Basic Principles and Guidelines Resolution]. See also Christopher Keith Hall, UN Convention on State Immunity: The Need for a Human Rights Protocol, 55 INT'L \& COMP. L.Q. 411, 413-14 (2006) (discussing how the rights of victims and their families to recover reparations for crimes under international law has been confirmed in a number of international instruments).

134 Paragraphs 19 and 20 of the U.N. General Assembly's Basic Principles and Guidelines Resolution, provides:

19. Restitution should, wherever possible, restore the victim to the original situation before the violations of international human rights law or serious violations humanitarian law occurred. Restitution includes, as appropriate: restoration of liberty; enjoyment of human rights, identity, family life and citizenship, return to one's place of residence, restoration of employment and return of property.

20. Compensation should be provided for any economically assessable damage, as appropriate and proportional to the gravity of the violation and the circumstances of each case, resulting from gross violations of international human rights law and serious violations of international humanitarian law, such as: (a) Physical or mental harm; (b) Lost opportunities, including employment, education and social benefits; (c) Material damages and loss of earnings, including loss of earning potential; (d) Moral damage; (e) Costs required for legal or expert assistance, medicines and medical services, and psychological and social services. (emphasis omitted).

Id. ๆ $19-20$.

135 Id. pmbl.

136 Id. See generally Roy L. Brooks, Getting Reparations for Slavery Right - A Response to Posner and Vermeule, 80 Notre DAME L. Rev. 251, 270-272 (2004) (outlining the different types of redress available to victims). 
participation of victims in the existing institutions of the societies in which they suffered historic injustices.

\section{INSTITUTIONAL REPARATIONS: THE SOUTH AFRICAN EXPERIMENT}

The human rights community and commentators have focused on the use of truth commissions, compensation, and restitution to respond to historic injustices. This focus has overshadowed the role of political, economic, and educational institutions in the reparations process. Although space does not allow for a full elaboration of the importance of these institutions in the reparations process, the remainder of this Article takes note of this theoretical limitation in the literature through consideration of the often-omitted role of economic institutions in the reparations process for groups subjected to historic injustices. ${ }^{137}$

The situation of post-apartheid South Africa illustrates the need for structural reparations to address the systemic exclusion of Blacks from land ownership, political participation, and economic ownership for most of the twentieth century. ${ }^{138}$ Rather than simply assessing South Africa's reparations policies, this Article will discuss the limitations of traditional reparations approaches and explore the possibility of remedying past injustices using a structured, institution-based approach. Although this Article uses South Africa as an example where this approach is being tested, space does not allow for a full-scale assessment of the quality and sufficiency of the government's implementation of the program. Instead, this Article serves to highlight the way that an institutional-based approach to reparations, rather than an individual-based approach, can address those structural injustices neglected by traditional reparations approaches while simultaneously fostering the moral agency of victims.

137 For a detailed discussion of the role of economic, political, and educational institutions in providing reparations for slavery and segregation to African Americans, see Carlton Waterhouse, The Full Price of Freedom: African American Responsibility to Repair the Harms of Slavery and Segregation (Aug. 2006) (unpublished Ph.D. dissertation, Emory University) (on file with author) (discussing in detail the role of economic, political, and educational institutions in providing reparations for slavery and segregation to African Americans).

138 Heather DeEgan, The Politics of THE New SOUTH Africa: APARTHEID AND After 3-67 (2001). The Australian aborigines, the Native Americans of North America, and African Americans represent additional groups who would benefit from structural reparations designed to produce long-term remediation of long standing injustices. See generally WHEN SORRY ISN'T ENOUGH, supra note 1. 
South Africa's Promotion of National Unity and Reconciliation Act directed the Reparations and Rehabilitation Committee of the Truth and Reconciliation Commission ("TRC") to consider matters referred to it by the Committee on Human Rights Violations and the Committee on Amnesty, in addition to its responsibility for recommending "urgent interim measures" for qualifying victims. ${ }^{139}$ Through these provisions, the legislation directed the Committee to consider individual applications for reparations and then determine awards for the victims of "gross violation[s] of human rights" that were consistent with the testimony received from the two other committees comprising the TRC.140 In theory, this two-tiered focus would allow the Reparations and Rehabilitation Committee to match individual reparations investigations with the corresponding testimony of victims regarding gross human rights violations and perpetrators in pursuit of amnesty. ${ }^{141}$ This process did not work as originally contemplated, however, since the provision of reparations experienced considerable delays relative to the grants of amnesty. ${ }^{142}$

139 Promotion of National Unity and Reconciliation Act 34 of 1995 ss. 25(1)(a)(i)(aa)-25(1)(a)(i)(bb), 25(1)(b)(i) (S. Afr.) [hereinafter Promotion of National Unity Act], available at http://www.doj.gov.za/trc/legal/act9534.htm. See also Penelope E. Andrews, Reparations for Apartheid's Victims: the Path to Reconciliation?, 53 DePAul L. REV. 1155, 1163-65 (2004) (describing how South Africa created the Truth and Reconciliation Commission to aid in addressing the issue of reparations).

140 Promotion of National Unity Act 34 of 1995 s. 25(1)(a)(i)-(1)(b)(i). This group of roughly 20,000 victims identified by the TRC pursuant to the statute contrasts with the millions of Black South Africans who suffered daily human rights abuses under apartheid from 1960 to 1994. See also Erin Daly, Reparations in South Africa: A Cautionary Tale, 33 U. MEM. L. REV. 367, 394-396 (2003) (arguing that in order for financial reparations to be implemented there must be a reasoned basis for relief).

141 Promotion of National Unity Act, s. 25(1)(a)(i). See also Marianne Geula, Note, South Africa's Truth and Reconciliation Commission as an Alternative Means of Addressing Transitional Government Conflicts in a Divided Society, 18 B.U. INT'L L.J. 57, 65-68 (2000) (describing the purpose and obligations of the Truth and Reconciliation Commission).

142 Alex Boraine, A COUNTRY UNMASKED: Inside SOUTH AFricA's TRUTH AND RECONCILIATION COMMISSION 334-35 (2000). Although the first Urgent Interim Reparations award took place in July 1998, from 1996 to 1998 the TRC had ruled on almost 200 amnesty applications. Members of the Reparations Committee expressed frustration that human rights violators received amnesty for their crimes long before their victims received reparations. Cf. Geula, supra note 141 (describing the purpose and obligations of the Truth and Reconciliation Commission). 
Ultimately, the TRC submitted a host of recommendations addressing the individual needs of victims, their relatives, and communities in addition to the broader society. ${ }^{143}$ Regarding the larger society, the TRC proposed the following: affirmative action programs for the business sector generally and the media sector specifically, the creation of a business reconciliation fund to finance Black entrepreneurship, land redistribution measures, compensation for loss of businesses or wages during the unrest of the 1980s and 1990s, and a mandatory scheme requiring restitution by business "for those who have suffered from the effects of apartheid discrimination." 144 In 1998 the TRC offered the following in its final report:

The road to reconciliation, therefore, means both material reconstruction and the restoration of dignity. It involves the redress of gross inequalities and the nurturing of respect for our common humanity. It entails sustainable growth and development in the spirit of ubuntu... It implies wideranging structural and institutional transformation and the healing of broken human relationships. It demands guarantees that the past will not be repeated. It requires restitution and the restoration of our humanity-as individuals, as communities and as a nation. ${ }^{145}$

To this end, the TRC recommended two forms of reparations for those persons it certified as claimants. ${ }^{146}$ The Reparations and Rehabilitation committee of the TRC recommended immediate reparations, titled "Urgent Interim Reparations," for those facing pressing needs at the time the Commission submitted its first report, and a long-term reparations program, titled Individual Reparations Grants, requiring payments over a six-year term for the entire class of recipients. ${ }^{147}$ The interim reparations

1435 Truth AND ReCONCILIATION COMMISSION OF SOUTH AFRICA RepORT 170-95 [hereinafter TRC REPORT VOL. 5].

144 TRC REPORT Vol. 5, supra note 143, at 304-49. See also Alfred L. Brophy, Some Conceptual and Legal Problems in Reparations for Slavery, 58 N.Y.U. ANN. SuRV. AM. L. 497, 499 (2003) (noting that discussions regarding affirmative action and discussions regarding reparations are often the same discussion).

1456 TRUTH AND RECONCILIATION COMMission OF SOUTH AFricA REPORT 138 [hereinafter TRC REPORT VOL. 6].

146 Id.

147 TRC REPORT VOL. 6, supra note 145 , at 165 . See also Daly, supra note 145 , at 391-92 (discussing the entities that would help deliver reparations to victims). 
recommended took the form of compensation for health care, education, housing, welfare and other services and included compensation as high as R12,000 (approximately U.S. \$1,630). ${ }^{148}$ However, after receiving the final volume of the TRC report on April 15, 2003, the President's Fund decided to provide a one-time payment of R30,000 (approximately U.S. \$3,842) to the 19,000 designated victims, totaling U.S. $\$ 85$ million. ${ }^{149}$ Under the TRC recommendation, however, the government would have provided up to R2.8 billion for Individual Reparations Grants (totaling \$360 million U.S.). ${ }^{150}$ This difference resulted from a philosophical disagreement between President Thabo Mbeki and the TRC regarding financial priorities and the benefits of individual reparations grants. President Mbeki viewed individual grants in the least favorable light, arguing that the transformation of society would be the best form of reparations for the victims of apartheid. ${ }^{151}$ The TRC, in contrast, viewed individual reparation grants as an important symbolic and material response to the victims of apartheid for the injustices they had suffered at the hands of the previous government. ${ }^{152}$ Therefore, in addition to recommending that victims be awarded reparation grants for the injustice they had suffered, South Africa's TRC included a Committee on Reparations and Rehabilitation that also recommended symbolic reparations. ${ }^{153}$

Despite the substantial recommendations by the Committee, South Africa's reparations process "has generated significant

148 TRC RePORT VOL. 6, supra note 145, at 172. See also Susan Ayres, Hélène Cixous's The Perjured City: Nonprosecution Alternatives to Collective Violence, 9 N.Y. CITY L. REV. 1, 27-28 (2005) (explaining that many believed TRC acknowledging victims' stories was affirming and healing for those victimized and characterizing TRC as an engine for collective healing).

149 Thabo Mbeki, President, South African, Statement to the National Houses of Parliament and the Nation at the Tabling of the Report of the Truth and Reconciliation Commission, 7 (Apr. 15, 2003) [hereinafter Mbeki, Report of the TRC], available at http://www.pmg.org.za/docs/2003/appendices /030610presrec.htm.

150 Brandon Hamber, Rights and Reasons: Challenges for Truth Recovery in South Africa and Northern Ireland, 26 FORDHAM INT'L L.J. 1074, 1079 (2003).

151 Mbeki, Report of the TRC, supra note 149. See Hamber, supra note 150, at 1079 (discussing the decision of President Mbeki to award a lower amount than recommended by the TRC Report).

152 TRC REPORT VOL. 6, supra note 145, at 105-09; Ayres, supra note 148, at 28.

153 Rose, supra note 57, at 387 (detailing that symbolic reparations might include memorials, reburials, renaming of streets and days of remembrance). 
dissatisfaction among victims."154 First, the government was very slow to respond to the TRC's recommendations about payments. ${ }^{155}$ Second, the Promotion of National Unity and Reconciliation Act, which authorized the formation of the TRC and outlined its responsibilities, included no requirements for reparations from the actual perpetrators or other beneficiaries of apartheid. 156

Under the United Nations Basic Principles and Guidelines on the Right to a Remedy and Reparation for Victims of Gross Violations of International Human Rights Law and Serious Violations of International Humanitarian Law, millions of South Africans arguably qualified for compensation based on physical and mental harm; lost opportunities; moral damage; and legal and medical expenses. ${ }^{157}$ The TRC reparations grants paled in comparison to the harms inflicted on South African Blacks, yet an award of compensation to the majority of South Africans was also untenable.158 The harms of apartheid could not be meaningfully redressed by a single $\mathrm{R} 30,000$ grant or a six year $\mathrm{R} 23,000$ award.159

Apartheid robbed the majority of South Africans of the skills and opportunities needed to participate fully in the economic sector of South African society. 160 In 1998, 85\% of the country's managers were white while, in addition, whites made up $93 \%$ and $92 \%$ respectively of the senior and executive managers. ${ }^{161}$ Blacks made up $15 \%$ of all levels of management and Native African women accounted for only $6 \%$ of the country's managers, though women represented roughly $35 \%$ of all management levels. 162 Of South Africans whose income reached R6,401 or more per month,

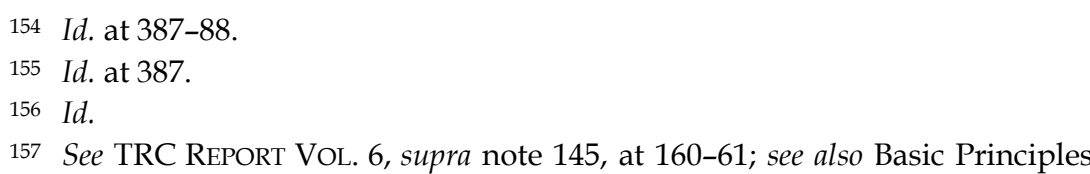
and Guidelines Resolution, supra note 133.

158 See TRC REPORT VOL. 6, supra note 145, at 161 (noting that, given its limited resources, providing reparations to over 20 million Black South Africans was not feasible); see also Rose, supra note 57, at 387-88 (asserting that despite TRC's recommendations, the reparations process in South Africa has not been satisfactory in the eyes of the victims).

159 See Rose, supra note 57, at 387 n.323 (detailing the Committee's proposed compensation to vicitims); see also Mbeki, Report of the TRC, supra note 149 (stating that a R30,000 grant would be provided to those victims designated by the TRC).

160 Mbeki, Report of the TRC, supra note 149.

161 DEEGAN, supra note 138, at 120.

162 Id. 
whites outnumbered Africans three to one, though in population Africans outnumbered whites eight to one. ${ }^{163}$ At the bottom of the income scale, the inverse was true: of South Africans making less than R1,600 per month, Blacks outnumbered whites eighteen to one. 164

To address the legacy of apartheid, the government passed a series of laws. ${ }^{165}$ These include: the Higher Education Act, the Skills Development Act, the Employment Equity Act, the Black Economic Empowerment Act, the Land Restitution and Reform Act, Restitution of Land Rights Act, and the Land Reform ("Labour Tenants") Act. 166 Although each of these address some reparative purpose relative to the history of apartheid, the rest of this Article will focus on the Employment Equity Act and the Black Economic Empowerment Act because of their direct relation to the society's economic institutions. Each of these statutes will be described in brief, including the reparative function they perform, before discussing the combined impact of the individual programs.

\subsection{The Employment Equity Act and the Black Economic} Empowerment Act

The Employment Equity Act establishes affirmative employment practices for training and hiring suitable persons from designated groups. ${ }^{167}$ For companies with fifty or more employees

163775,165 whites in South Africa earned R6401 per month or more. In contrast, only 223,116 Native Africans did so. For every Native African making $\mathrm{R} 6,401$ or more per month, there were three whites making as much or more. StATISTICS SOUTH AFriCA, CENSUS 2001: PRIMARY TABLES SOUTH AFrICA 74 tbl.16.3 (2001), available at http://www.statssa.gov.za/census01/HTML/RSAPrimary .pdf.

$1644,241,371$ native Blacks make R1,600 or less per month. Only 237,505 whites made R1,600 or less per month. Accordingly, for every white person making R1,600 or less per month, there are eighteen Blacks in the same income range. $I d$.

165 Broad-Based Black Economic Empowerment Act 53 of 2003 (S. Afr.); Land Restitution and Reform Amendment Act 18 of 1999 (S. Afr.); Skills Development Act 97 of 1998 (S. Afr.); Employment Equity Act 55 of 1998 (S. Afr.); Higher Education Act 101 of 1997 (S. Afr.); Land Reform (Labour Tenants) Act 3 of 1996 (S. Afr.); Restitution of Land Rights Act 22 of 1994 (S. Afr.)..

166 Id. See also F. Michael Higginbotham, Affirmative Action in the United States and South Africa: Lessons From the Other Side, 13 TEMP. INT'L \& COMP. L.J. 187, 21314 (1999) (describing the support for affirmative action and the Employment Equity Act in South Africa).

167 Designated groups consist of Black South Africans, women, and people with disabilities. Employment Equity Act 55 of 1998 s. 5.1 (S. Afr.). Black South 
or with substantial annual receipts for their industry, the Act requires numerical goals and preferential treatment to ensure equitable representation. ${ }^{168}$ The Act directs employers to implement measures identifying and eliminating employment barriers that adversely affect people from designated groups; further diversity in the workplace; make reasonable accommodation for people from designated groups to ensure representation; and implement appropriate training measures. ${ }^{169}$

The specified purpose of the Employment Equity Act includes: "Implementing affirmative action measures to redress the disadvantages in employment experienced by designated groups, in order to ensure their equitable representation in all occupational categories and levels in the workforce."170 As a reparative measure, the Act seeks to create job opportunities and training across professions and career paths for Blacks excluded from occupying most positions under apartheid. ${ }^{171}$ The goal of the Act is to bring the masses of the South African population slowly into offices, positions, and career paths consistent with their numerical representation within the society. ${ }^{172}$

In South Africa, this means the reversal of a century-long structural exclusion of these groups from gaining the training and skills required for these jobs, as well as the economic benefit of the higher salaries they provide. Because the Act mandates implementation at all levels for designated employers, its faithful implementation will racially reform those institutions, ensuring that the victims of apartheid benefit from the power and positions

Africans include native Africans, Indians, and people of color. See generally Karin van Marle, "Meeting the World Halfway" - The Limits of Legal Transformation, 16 FLA. J. INT'L L. 651, 658-60 (2004) (discussing the limitations of the definition of designated groups in the context of employment integration).

168 Employment Equity Act 55 of 1998 s. 5.1 (S. Afr.) (“designated employer).

169 Id. s. 15(2).

170 Id. s. 2.

171 Id. s. 2 (noting that the Act seeks to create jobs for South African Blacks). But see Elizabeth Hoffman, A Wolf in Sheep's Clothing: Discrimination Against the Majority Undermines Equality, While Continuing to Benefit Few Under the Guise of Black Economic Empowerment, 36 SYRACUSE J. INT'L L. \& COM. 87, 103-04 (2008) (referencing Phinda Madi, a well known Black critic of Broad-Based Black Economic Empowerment, who argues that while a job would be extremely empowering for most South Africans, Black Empowerment has created almost no new jobs but rather has reinforced the economic divides put in place by apartheid without adding a mechanism to destroy them).

172 See Employment Equity Act 55 of 1998 s. 2 (S. Afr.) (calling for a workforce representative of the South African people). 
from which they were excluded. Although the process will likely take a generation or more for completion due to the extreme level of deprivation caused by apartheid, it ultimately places Blacks, along with whites, in control of the economic institutions of the nation. This program operates primarily as an individual rather than communal-based approach to reparations, however, the transfer of power within these institutions to the former victims of apartheid results in the redistribution of the benefits associated with their operation, as well as those gained from the positions held within them. In the South African context, where the apartheid victims constitute the majority of the population, this methodology addresses a significant aspect of the group-based injury caused by apartheid. The status, money, and power associated with positions obtained through the Act directly reverse the former denial of the same positions based on race.

Substantial debate exists regarding the benefits of affirmative action and related programs in both the United States and South Africa. As a nation in transition, South Africa's approach may be viewed as unique to situations of transitional justice andd inapplicable to other frameworks. ${ }^{173}$ However, the distinction between ordinary and transitional justice should not be overstated. ${ }^{174}$ South Africa employs affirmative action along with a host of other reparative programs, all of which should be viewed as part of a comprehensive strategy to redress the harms of apartheid. ${ }^{175}$ The program in the United States originated along

173 For an examination of transitional justice theory see RUTI TEITEL, TRANSITIONAL JUSTICE (2000).

174 A rigid distinction between transitional and ordinary periods neglects the dynamic nature of justice and the importance of backward-looking justice, not just in transitional periods but at all times. See Aeyal M. Gross, The Constitution, Reconciliation, and Transitional Justice: Lessons From South Africa and Israel, 40 STAN. J. INT'L L. 47, 50-52 (2004) (critiquing Teitel and the theory of transitional justice).

175 The debate over affirmative action as a tool for addressing historic injustices continues. See ThOMAs SOWEll, AfFirmative ACTION ArOUnd THE World: AN EMPIRICAL STUDY 166-84 (2004); see also, FAYE J. CROSBy, AFFIRMATIVE ACTION Is DEAD: LONG Live AfFiRMATIVE ACTION 221-39 (2004) (discussing and evaluating the debate over affirmative action). For a favorable examination of affirmative action policies in the United States and South Africa see Higginbotham, supra note 166; see also Adila Hassim, Affirmative Action Policies in The United States and South Africa: A Comparative Study, 2000 ST. LOUIS-WARSAW TRANSATLANTIC L.J. 119 (2000) (comparing the history and positive functions of affirmative action in the United States and South Africa). 
similar lines. ${ }^{176}$ Because of the historic discrimination against Blacks and others, the American government instituted affirmative action in hiring and contracting in the wake of the civil rights movement as a way to remedy the discrimination of the past. ${ }^{177}$

However, South African programs should be distinguished from the United States' affirmative action program on two primary bases: the continued minority status of Black beneficiaries in the U.S. context; and the limited scope of the American program. Affirmative action in the United States could have functioned reparatively to remedy some harm of slavery and segregation; however, as designed and implemented it failed to do so. ${ }^{178}$ The continued minority status of Blacks in the United States, coupled with the persistence of racism, restricted the ability of Blacks to gain offices and positions in American society that they and their ancestors were denied based on race. The limited scope of mandatory affirmative action in America further exemplifies this point. Affirmative action regulation was restricted to government positions and contractors and never applied to large segments of the private sector. ${ }^{179}$ Furthermore, even the affirmative action programs guiding government contracting only resulted in a five percent set-aside under some federal programs for women, minorities, and other small disadvantaged businesses combined, though they comprise the majority of the country's population. ${ }^{180}$

The South African program, in contrast, places the country's vast resources in the hands of the former victims, providing them with an institutional structure to support the long-term remediation of the harms of apartheid.181 This is not to suggest that affirmative action should be viewed as a panacea or even a potential cure for all of South Africa's ills. Rather, this Article seeks to emphasize the program's potential to provide new

176 See Philip Rubio, A History of Affirmative Action: 1619-2000, at 135 166 (2001) (detailing the advent and development of affirmative action from 1955 through 1993).

177 Id.

$178 I d$. at 188 (estimating the damage of slavery as far exceeding the value of all benefits accorded Blacks in subsequent years).

179 See Roy L. Brooks, Gilbert Paul Carrasco \& Gordon A. Martin, Jr., CiviL RigHTS LiTIGATION 1071-1171 (1995) (examining affirmative action case law).

180 See the National Defense Authorization Act for 1986, Pub. L. No. 99-661, § 1207, 100 Stat. 3973-75 (establishing a 5\% contract goal on Department of Defense awards to small disadvantaged businesses).

181 See supra note 156 and accompanying text. 
opportunities to large numbers of South Africans that will enable them to take an active role in redressing the historic discrimination of the South African employment sector through their role in staffing and managing the nation's businesses. The Black Economic Empowerment Act ("BEE") also promotes an institutional approach to remedying apartheid's harms. Under the terms of this Act, companies doing business with the South African government or any organ of the state for procurement, licensing, or public-private partnerships, must diversify their equity ownership to include Blacks at levels set by the cabinet members that oversee the particular industries. ${ }^{182}$ The Act has increased integration and Black South Africans have become increasingly empowered in the business sector since 1994. Some Blacks occupy positions in senior management or on the Boards of Directors of South African companies. ${ }^{183}$ However, as Tangri and Southall note:

It has also been observed that the number of black managers in the private sector is still small and black people are hardly in controlling positions in capital. In an October 2005 report released by the Black Business Executive Circle, it was recorded that only five of the Johannesburg Securities Exchange ("JSE") top 200 companies had black ownership of more than 51 percent, only 27 companies had more than 25 percent, and these 32 companies together accounted for less than 2 percent of the JSE's market capitalization. ${ }^{184}$

Along with set targets, officials use a scorecard that examines the following indicators of economic involvement: direct empowerment through ownership and control of enterprises and assets; procurement from the aforementioned designated groups; the development of enterprises involving designated groups; and corporate investment that benefits members and communities from

182 Broad-Based Black Economic Empowerment Act 53 of 2003 s. 9 (S. Afr.). See generally Daniel M. Ludlam, From Mandela and MLK to BEEcom and the SBA: Laying the Groundwork For Equality Through Business Development Programs in South Africa and the United States, 35 GA. J. INT'L \& COMP. L. 369, 389-90 (2007) (discussing the importance of achieving the goals advanced by the preamble of the BEE).

183 See Roger Tangri \& Roger Southall, The Politics of Black Economic Empowerment in South Africa, 34 J.S. AFR. STUD. 699, 700 (2008) (discussing the changes in Black South African involvement in the business sector).

184 Id. at 700. 
the designated groups and other workforce-related categories. ${ }^{185}$ This program could provide substantial institutional reparations through redistributing ownership of South Africa's corporations to the victims of apartheid.

Criticisms of the BEE abound. Substantial challenges exist to enable it to meet its potential. 186 Because the program has turned some ANC elites into instant millionaires, critics see it as a vehicle for enriching the party faithful rather than a genuine means of transforming South African society. ${ }^{187}$ The early criticism of the BEE's exclusive enrichment of a few individuals seems well placed. To meet its reparative potential, the benefit of equity ownership in South Africa's businesses must be spread across those communities and groups harmed by apartheid in order to remedy the exclusionary practices of the previous political and economic regime. In response to the perceived abuse and the narrow initial approach to the program, the government has more recently directed the program to communities, civil society, and workers. This approach flows from the adoption of a broad-based BEE ("BBBEE") "aimed at redressing the imbalances of the past by seeking to substantially and [sic] equitable transfer ownership, management, and control of South Africa's financial and economic resources to the majority of its citizens." 188 However:

185 Id. at 706. See also S. Afr. DEP'T OF TRADE AND INDUSTRY, SOUTH AFricA's ECONOMIC TRANSFORMATION: A STRATEGY FOR BROAD-BASED BLACK ECONOMIC EMPOWERMENT 4-12 (2003), available at http://www.thedti.gov.za/bee/bee.htm (studying the lasting influences of apartheid, and the success of BEE initiatives to achieve economic integration).

186 As a part of the ANC's adoption of a neo-liberal market philosophy to transform South African society, the BEE faces many of the same criticisms. See IAN TAYLOR, STUCK IN MIDDlE GEAR: SOUTH AFRICA's POST APARTHEID ForEIGN RELATIONS 67-83 (2001) (analyzing and critiquing the ANC's move away from their more radical socialist ideology to a right-of-center economic approach that protects business and investment); HEIN MARAIS, SOUTH AFRICA: LIMITS TO CHANGE: THE POLITICAL ECONOMY OF TRANSITION 160-95 (2001) (explaining how the ANC, like many other such movements quickly adopted a less drastic, more business and capital friendly economic structure after assuming power).

187 William M. Gumede, Down to Business But Nothing to Show, in THABO MbeKI's World: THE POLITICS AND IDEOLOGY OF THE SOUTH AFRICAN PRESIDENT 20710 (Sean Jacobs \& Richard Calland eds., 2002) (noting that many BEE measures benefit a small elite-often comprised of former ANC members who left politics to pursue business - at the expense of the Black majority); See also Tangri \& Southall, supra note 183, at 704 (highlighting the failure to the BEE initiatives to achieve meaningful integration of Blacks into the white economy).

188 Gumede, supra note 187, at 214. 
While BBBEE was created to make South Africa's economy more representative of the demographic makeup of the country, major structural flaws have continued to disempower the black majority. These flaws include, but are not limited to, the focus on black ownership and management, lack of mandatory compliance with BBBEE policy, the economic rise of "black diamonds," and the continuation of a small class of economic dominance. ${ }^{189}$

Succeeding in this task presents a challenge that will require greater governmental monitoring and private sector cooperation than has occurred so far. ${ }^{190}$ The potential offered by the program to redress some of the economic harms of apartheid and to enable its former victims to own, control, and participate in the institutions that once excluded them, underscores the potential of institutional based reparations to redress deep structural inequities untouched by the prevailing models of reparations. ${ }^{191}$ In short, institutionally-based reparations that focus on providing the former victims of human rights abuses with the ability to own and manage the resources from which they were formerly excluded represent an important and under-explored reparations mechanism. ${ }^{192}$

Beyond the position, status, and income redistributed by the Employment Equity Act, the BBBEE can potentially redistribute wealth in South African society and the power that accompanies it. Moreover, this institutional mechanism for addressing the harms of apartheid in South Africa highlights the way that institutional reparations can alter the fundamental distribution of goods in a society and its communities. Together these two Acts, taken along with political reforms that place the former apartheid victims in

189 Hoffman, supra note 171 , at 96.

190 Gumede, supra note 187, at 215-16 (explaining that critical to Mbeki's probusiness strategy is greater willingness from the government and the middle management sector to cooperate in the transformative change of South African business and society).

191 Id.

192 This approach fits into the transformative model of justice that focuses on institutional changes that transform the society at multiple levels rather than a mere governmental transition. See Erin Daly, Transformative Justice: Charting A Path To Reconciliation, 12 INT'L LEGAL PERSP. 73, 74 (2002) (explaining the role of the Truth and Reconciliation Commission in transforming South African society as a whole, in contrast to mere top-down regulations that allow a transition of power without deeper transformation of society). 
positions of power, can change the institutional structure of the South African economic sector. The distinctness of these institutional approaches underscores my argument that reparations focused on reforming or creating institutional structures can create a wealth of new opportunities for harmed communities, their individual members, and the societies in which they operate. Moreover, unlike the passive receipt of compensation, participation in South Africa's institutionally based programs can empower victims to engage their society as political and economic agents who play a vital role in shaping its future. Clearly, the successful implementation of institutional schemes in the South African context also faces many challenges. ${ }^{193}$

\section{CONCLUSION}

This Article's analysis suggests the use of measures as criteria for assessing reparations programs. Although a full elaboration of such measures will be the subject of future research, a brief consideration of some essential measures is in order. Scope, scale, structural inclusion, accessibility, and procedural inclusiveness serve as significant criteria for assessing reparations programs and the role of victims within them. The scope of a program describes the range of harms redressed within a reparations scheme. Programs that exclusively address limited types of harm such as property loss or physical injury have a narrow scope. The Asian Women's Fund established for victims of the Japanese Army was very narrow in its scope. ${ }^{194}$ In contrast, programs that recognize and respond to an assortment of harms flowing from human rights abuses are broad in scope. Scale speaks to the substantive value or depth of the redress provided. This measure focuses on the amount or extent of redress. The compensation scheme used in Argentina that provided former detainees with awards based on mid to high level civil servant salaries called for high scale redress. ${ }^{195}$ Structural inclusiveness relates to the breadth of victims

193 See generally MARAIS, supra note 186 (assessing the substantial obstacles facing the ANC's market-based approach to societal transformation); GUY ARNOLD, THE NEW SOUTH AFRICA (2000) (discussing the huge political and economic changes in South Africa from 1994 to 1998, and considering the vast challenges facing the country under Mbeki's rule).

194 WHEN SORRY ISN'T ENOUGH, supra note 1, at 128-131.

195 Guembe, supra note 80, at 31-44 (2006) (explaining that for each day of proven detention, victims received $1 / 30$ the monthly salary of the highest paid category of civil servants). 
covered under a program. One of the biggest shortcomings of the FRG reparations program was its exclusion of whole classes of victims such as the Roma who also suffered under the Nazi regime. 196 Argentina, in contrast, extended its program to the broadest range of victims; achieving a high degree of structural inclusiveness. ${ }^{197}$ Procedural inclusiveness examines the level of victim involvement in reparations program development. The Federal Republic of Germany's negotiation of reparations terms with Jewish victim's groups in the wake of World War II demonstrates significant procedural inclusiveness although the range of victim classes involved was limited. The accessibility assesses victims' ability to obtain or make use of reparations. The Indian Claims Commission as a mechanism for redress represented the lowest degree of accessibility; it forced victims to conform to a highly bureaucratic adversarial process foreign to them and their way of life. ${ }^{198}$ Overall, it impeded rather than facilitated redress.

This failure to attend to the basic needs of the programs beneficiaries reflects the frequent shortcoming of reparations programs from victims' perspectives. By reframing program development in light of victims' needs and perspectives, future programs will hopefully lead to more "good" if not better reparations programs. Making sure that all victims can take advantage of opportunities and participate equally in reforms, minimizing resentment held by other members of society not directly benefiting from reparative programs, and ensuring that new or reformed institutions deal fairly and openly within the society represent a few of the many difficulties that reparations programs need to address. Developing more inclusive reparations programs that engage victims in their design and implementation serves an overlooked but important role in the process of redressing historic injustices.

196 Kim, supra note 10, at 77 (emphasizing that the failure of the German reparations program was the classes of victims excluded from the process who have "suffered in relative silence").

197 Guembe, supra note 80.

198 Newton, supra note 79, at 262-64. 